\title{
Determination of Growth Curves in Young Angora Goats
}

\author{
Havva ÖZDEMIR ${ }^{1}$ \\ Gürsel DELLAL ${ }^{1}$ \\ Received: September 02, 2008 \\ Accepted: September 15, 2009
}

\begin{abstract}
The aim of this study is to analyze the growth curves of young Angora goats by using live weight data during period between birth and $12^{\text {th }}$ months. To reach this aim Logistic and Gompertz models which are non-linear growth models were used. To estimate growth, the determination coefficients of Logistic and Gompertz growth models were found as $R^{2}=0.957$ and $R^{2}=0.956$, respectively. According to these coefficients it might be suggested that it could be suitable to use both growth models in order to define the changes in the live weights as to time in young Angora goats.
\end{abstract}

Key Words: Angora goat, live weight, growth curve

\section{Genç Ankara Keçilerinde Büyüme Eğrilerinin Belirlenmesi}

Öz: Bu çalışmada, genç Ankara keçilerinde doğum ve 12 aylık yaş arasındaki dönem esnasında canlı ağırlıklara ait veriler kullanılarak büyüme eğrileri analiz edilmiştir. Bu amaçla doğrusal olmayan büyüme modellerinden Logistic ve Gompertz modelleri kullanılmıştır. Logistic ve Gompertz büyüme modellerinin büyümeyi tahmin etmedeki doğruluk dereceleri sırasıyla $R^{2}=0.957$ ve $R^{2}=0.956$ olarak saptanmıştır. Bu katsayılara göre, genç Ankara keçilerinde canlı ağırlıkta zamana göre meydana gelen değişimleri tanımlamak için her iki büyüme modelinin de kullanılması uygun olabilir.

Anahtar Kelimeler: Ankara keçisi, canlı ağırlık, büyüme eğrisi

\section{Introduction}

The most important characteristic of live material is growth, and describe as an increase in both the weight and size of live material in a certain period of time (Thornley and Johnson 1990). In animal production the majority of products, especially meat production, are affected by growth rate and body size of animal. For this reason the studies on growth in the animal production has been increasing.

The scientific analysis of growth requires mathematical models running with data obtained from growth periods. Thus events with growth are more clearly explained and interpreted (Efe 1990).

The growth curves are one of the ways of scientific description of growth in a certain period of time. The models of Gompertz, Richards, Bertalanffy and Monomolecular are generally used as the mathematical growth models to analyze the curves of growth (Finney 1978). The shape of the growth curve may change according to the genotype of live material, environmental conditions and investigated characteristics (Efe 1990). The growth curves are used in the early selection in order to estimate the growth of animal in the future ages (Efe 1990, Tekel 1998).

In this study the growth curves of young Angora goats for live body weight data from birth to $12^{\text {th }}$ months of ages were analysed by Logistic and Gompertz growth models.

\section{Materials and Methods}

This research was carried out in Angora goats (37 heads) in Yerkoy Animal Research Institute of Yozgat Province. The live weights of kids were measured with monthly periods from birth to $12^{\text {th }}$ months of ages.

The following mathematical model was constituted to determine the effects of birth type and sex on the period live weights:

\footnotetext{
${ }^{1}$ Ankara University, Faculty of Agriculture, Department of Animal Science, 06110 Diskapi, Ankara, Turkey
} 


\section{$Y_{i j k}=\mu+a_{i}+b_{j}+e_{i j k}$}

In this model;

$Y_{i j k}=$ live weight of $k_{t h}$ kid's born in $i_{t h}$ birth type and $j_{\text {th }} \operatorname{sex}$

$\mu=$ population mean,

$\mathrm{a}_{\mathrm{i}}=$ deviations, mean of kids born in $\mathrm{i}_{\mathrm{th}}$ birth type from population mean,

$\mathrm{b}_{\mathrm{j}}=$ deviations, mean of kids born in $\mathrm{j}_{\text {th }}$ sex from population mean,

$e_{i \mathrm{ijk}}=$ constitutes the effects of random factors on $\mathrm{k}_{\text {th }}$ kid born in $\mathrm{i}_{\text {th }}$ birth type and $\mathrm{j}_{\text {th }}$ sex.

The growth in early periods of animals can be analyzed by growth curves drawn by linear growth models but due to changing of linearity of growth in the forward periods, the non-linear growth models are used to analyze of growth in this period (Çıtak et al 1998). For this reason, in this study, to analyze the growth between birth and $12^{\text {th }}$ months of ages of young Angora goats, the Logistic and Gompertz non-linear models were used for drawing of growth curves. The corrected data were used for drawing of growth curves. These models were described as follows:

Logistic growth model;

$W=A /\left(1+b^{*} \exp \left(-k^{*} t\right)\right)$

Gompertz growth model;

$W=A^{*}\left(1-b^{*} \exp \left(-k^{*} t\right)\right)$

In these models;

W: Live weight,

A: $t \rightarrow \infty$ Predicted mature live weight,

b: Folding point of growth $(\mathrm{t}=0)$,

k: Growth rate,

exp: Natural logarithm base,

t: Time.

The SPSS software program was used for predictions of parameters of non-linear growth models (SPSS 1994).

\section{Results and Discussion}

Descriptive statistics: The descriptive values of live weight of the young Angora goats from the birth to $12^{\text {th }}$ months of ages were given in Table 1 . As presented in Table 1, the general means of live weight in the young Angora goats from the birth to $12^{\text {th }}$ months of ages were $2.8 \pm 0.06,5.5 \pm 0.16,8.2 \pm 0.31$,

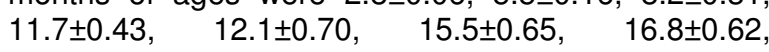
$17.4 \pm 0.60, \quad 17.6 \pm 0.82, \quad 16.9 \pm 0.67, \quad 18.3 \pm 0.84$,
$19.2 \pm 0.90$ and $19.5 \pm 0.95 \mathrm{~kg}$, respectively. The effect of sex on the live weights of young Angora goats in the $3^{\text {rd }}, 5^{\text {th }}, 6^{\text {th }}, 7^{\text {th }}, 8^{\text {th }}, 10^{\text {th }}, 11^{\text {th }}$ and $12^{\text {th }}$ months was important $(\mathrm{P}<0.01)$ and young male Angora goats had higher values of live weight than those of young females. However, the effect of birth type on the live weights was found significantly important $(P<0.01)$. Only birth period and the birth weights of kids born as single were higher than those of kids born as twins (Table 1).

\section{Growth Curves}

The parameter values and determination coefficients estimated by Logistic and Gompertz growth models for live weight of young Angora goats are given in Table 2. As seen in Table 2, in this study, to estimate live weights from the birth to $12^{\text {th }}$ months of ages in young Angora goats, the determination coefficients of Logistic and Gompertz growth models were quite high and similar $\left(R^{2}=0.957\right.$ and 0.956 , respectively). In addition the values of A-constant which means the highest weight value in the used model were estimated as 20.70 and 23.39 for Logistic and Gompertz model, respectively. These findings were accorded with the findings from Scottish Blackface, Welsh Mountain and Shetland lambs (Friggens et al. 1997), some lambs of European sheep breeds (Zygoyiannis et al. 1997), Dorset Down X White Karaman lambs (Şireli 2002), Kilis goat kids (Çıtak at al. 1998; Kuzu 2001), female White goat kids ( Kor et al. 2006) and Tunisian native goat ( Najari et al. 2007a).

In young Angora goats, the growth curves drawn for live weight using Logistic and Gompertz growth models are given in Figure 1 and 2 , respectively. When the values of weight and height of animals from birth to death are analyzed by growth models, the shapes of obtained growth curves are generally be straight ' $S$ ' shape that is termed as "sigmoidal curve"(Yakupoğlu 1999). As seen in the Figure 1 and 2, similar growth curves drawn by Logistic and Gompertz growth models during several months after birth in the Angora goat kids showed closely linear model but this linearity altered during the forward periods and the shape of growth curves closed to sigmoidal curve.

Obtained growth curves of Angora goat kids based on Logistic and Gompertz growth models showed similarity with the growth curves estimated by both models in the studies on Dorset Down $x$ White Karaman lambs ( Şireli 2002), Awassi lambs (Tekel 2005), male Norduz lambs (Karakuş et al. 2008 ), and Tunisian native goat kids( Najari et al. 2007b). 
Table 1. Descriptive statistics of live weight in young Angora goats

\begin{tabular}{|c|c|c|c|c|c|c|c|}
\hline Periods & \multicolumn{2}{|c|}{ Factors } & $\mathrm{N}$ & $\bar{X} \pm S_{\bar{X}}$ & Minimum & Maximum & $\begin{array}{l}\text { Coefficient of } \\
\text { Variation }(\%)\end{array}$ \\
\hline \multirow{5}{*}{ At birth } & \multirow{2}{*}{ Type of birth } & Single & 30 & $2.96 \pm 0.06^{*}$ & 2 & 3.50 & 10.13 \\
\hline & & \begin{tabular}{|l} 
Twin \\
\end{tabular} & 7 & $2.71 \pm 0.06$ & 2.4 & 2.9 & 6.76 \\
\hline & \multirow{2}{*}{ Sex } & Male & 22 & $2.88 \pm 0.05$ & 2.6 & 3.50 & 8.55 \\
\hline & & Female & 15 & $2.79 \pm 0.05$ & 2 & 3.40 & 12.45 \\
\hline & \multicolumn{2}{|l|}{ General } & 37 & $2.8 \pm 0.06$ & 2 & 3.50 & 10.20 \\
\hline \multirow{5}{*}{ 1. month } & \multirow{2}{*}{ Type of birth } & Single & 30 & $5.6 \pm 0.16$ & 4 & 7.30 & 13.75 \\
\hline & & Twin & 7 & $5.5 \pm 0.16$ & 4.9 & 7 & 13.24 \\
\hline & \multirow{2}{*}{ Sex } & Male & 22 & $5.7 \pm 0.13$ & 4.3 & 7.30 & 13.98 \\
\hline & & Female & 15 & $5.4 \pm 0.13$ & 4.1 & 6.6 & 12.44 \\
\hline & \multicolumn{2}{|l|}{ General } & 37 & $5.5 \pm 0.16$ & 4.1 & 7.30 & 13.50 \\
\hline \multirow{5}{*}{ 2. month } & \multirow{2}{*}{ Type of birth } & Single & 30 & $8.1 \pm 0.31$ & 5.3 & 11.6 & 17.97 \\
\hline & & Twin & 7 & $8.3 \pm 0.31$ & 7.3 & 11.40 & 17.6 \\
\hline & \multirow{2}{*}{ Sex } & Male & 22 & $8.5 \pm 0.25$ & 5.8 & 11.6 & 18.78 \\
\hline & & Female & 15 & $8.0 \pm 0.25$ & 5.3 & 10 & 15.72 \\
\hline & General & & 37 & $8.2 \pm 0.31$ & 5.3 & 11.6 & 17.6 \\
\hline & & Single & 30 & $11.5 \pm 0.44$ & 6.8 & 15.30 & 18.67 \\
\hline & Type of birth & Twin & 7 & $12.0 \pm 0.44$ & 8.8 & 15.7 & 20.85 \\
\hline 3. month & Soy & Male & 22 & $12.7 \pm 0.35^{\star}$ & 9.3 & 15.7 & 15.58 \\
\hline & sex & Female & 15 & $10.8 \pm 0.35$ & 6.8 & 14.6 & 20.19 \\
\hline & General & & 37 & $11.7 \pm 0.43$ & 6.8 & 15.7 & 18.8 \\
\hline & Tung of hirth & Single & 30 & $13.0 \pm 0.71$ & 3.9 & 18.50 & 24.95 \\
\hline & I ype of birth & Twin & 7 & $11.3 \pm 0.71$ & 9.2 & 13.30 & 14.77 \\
\hline 4. month & & Male & 22 & $12.0 \pm 0.55$ & 3.9 & 18.50 & 26.62 \\
\hline & Sex & Female & 15 & $12.2 \pm 0.55$ & 7.8 & 17.30 & 21.57 \\
\hline & General & & 37 & $12.1 \pm 0.70$ & 3.9 & 18.50 & 24.20 \\
\hline & & Single & 30 & $16.5 \pm 0.66$ & 9.8 & 23.50 & 20.19 \\
\hline & I ype of birth & Twin & 7 & $14.4 \pm 0.66$ & 12.8 & 14.8 & 6.17 \\
\hline 5. month & & Male & 22 & $16.8 \pm 0.51^{*}$ & 13.2 & 23.50 & 16.26 \\
\hline & Sex & Female & 15 & $14.1 \pm 0.51$ & 9.8 & 20.6 & 20.80 \\
\hline & General & & 37 & $15.5 \pm 0.65$ & 9.8 & 23.50 & 20.20 \\
\hline & & Single & 30 & $17.1 \pm 0.62$ & 10 & 24.50 & 18.86 \\
\hline & I ype of birth & Twin & 7 & $16.6 \pm 0.62$ & 13.5 & 23.6 & 20.83 \\
\hline 6. month & Sey & Male & 22 & $18.5 \pm 0.50^{\star *}$ & 14.5 & 24.50 & 15.62 \\
\hline & sex & Female & 15 & $15.2 \pm 0.50$ & 10 & 20.10 & 18.79 \\
\hline & General & & 37 & $16.8 \pm 0.62$ & 10 & 24.50 & 19.10 \\
\hline & & Single & 30 & $17.5 \pm 0.61$ & 10 & 24.9 & 18.67 \\
\hline & Type of birth & Twin & 7 & $17.2 \pm 0.61$ & 13.9 & 22.30 & 16.30 \\
\hline 7. month & & Male & 22 & $19.0 \pm 0.50^{\star *}$ & 14.9 & 24.9 & 14.95 \\
\hline & Sex & Female & 15 & $15.8 \pm 0.50$ & 10 & 20 & 17.62 \\
\hline & General & & 37 & $17.4 \pm 0.60$ & 10 & 24.9 & 18.20 \\
\hline & & Single & 30 & $18.3 \pm 0.83$ & 10.9 & 35.40 & 23.60 \\
\hline & Type of birth & Twin & 7 & $16.9 \pm 0.83$ & 13.1 & 23.8 & 22.15 \\
\hline 8. month & Sey & Male & 22 & $19.6 \pm 0.66^{\star *}$ & 15.2 & 35.40 & 22.59 \\
\hline & Sex & Female & 15 & $15.6 \pm 0.66$ & 10.9 & 20 & 16.15 \\
\hline & General & & 37 & $17.6 \pm 0.82$ & 10.9 & 35.40 & 23.6 \\
\hline & Tune of hirth & Single & 30 & $16.8 \pm 0.67$ & 11.5 & 22.9 & 17.03 \\
\hline & Iуре of Dirth & Twin & 7 & $16.9 \pm 0.67$ & 11.9 & 24 & 26.95 \\
\hline 9. month & & Male & 22 & $17.9 \pm 0.54$ & 11.5 & 24 & 18.65 \\
\hline & Sex & Female & $\frac{L L}{15}$ & $15.8 \pm 0.54$ & 11.9 & 20 & 17.04 \\
\hline & General & & 37 & $16.9 \pm 0.67$ & 11.5 & 24 & 18.9 \\
\hline & Tyne of hirth & Single & 30 & $18.0 \pm 0.84$ & 12 & 26.6 & 20.98 \\
\hline & I ype of birth & Twin & 7 & $18.7 \pm 0.84$ & 12.9 & 27.6 & 29.21 \\
\hline 10. month & Sey & Male & 22 & $20.3 \pm 0.65^{\star *}$ & 13 & 27.6 & 19.73 \\
\hline & Sex & Female & 15 & $16.4 \pm 0.65$ & 12 & 21.8 & 19.40 \\
\hline & General & & 37 & $18.3 \pm 0.84$ & 12 & 27.6 & 22.20 \\
\hline & Tuno of hirth & Single & 30 & $18.7 \pm 0.90$ & 12 & 27.8 & 22.21 \\
\hline & I ype of birth & Twin & 7 & $19.7 \pm 0.90$ & 13 & 28.8 & 33.64 \\
\hline 11. month & Sey & Male & 22 & $22.0 \pm 0.68^{\star \star}$ & 15.8 & 28.8 & 18.13 \\
\hline & sex & Female & 15 & $16.4 \pm 0.68$ & 12 & 22.8 & 20.51 \\
\hline & General & & 37 & $19.2 \pm 0.90$ & 12 & 28.8 & 23.7 \\
\hline & & Single & 30 & $19.1 \pm 0.95$ & 12 & 28.8 & 23.77 \\
\hline & Type of birth & \begin{tabular}{|l} 
Twin \\
\end{tabular} & 7 & $20.0 \pm 0.95$ & 13 & 29.8 & 35.24 \\
\hline 12. month & & Male & 22 & $22.7 \pm 0.70^{\star \star}$ & 16.8 & 29.8 & 18.21 \\
\hline & Sex & Female & 15 & $16.4 \pm 0.70$ & 12 & 23.8 & 21.57 \\
\hline & General & & 37 & $19.5 \pm 0.95$ & 12 & 29.8 & 25.20 \\
\hline
\end{tabular}

${ }^{*} \mathrm{P}<0.05,{ }^{* *} \mathrm{P}<0.01$ 
Table 2. The parameters values and determination coefficients $\left(R^{2}\right)$ estimated by Logistic and Gompertz growth models for live weight in the young of young Angora goat.

\begin{tabular}{|c|c|c|}
\hline Parameters & LOGISTIC & GOMPERTZ \\
\hline $\mathrm{A}$ & 20.7041 & 23.394 \\
$\mathrm{~b}$ & 4.966 & 0.910 \\
$\mathrm{k}$ & 0.019 & 0.0069 \\
$\mathrm{R}^{2}$ & 0.957 & 0.956 \\
\hline
\end{tabular}

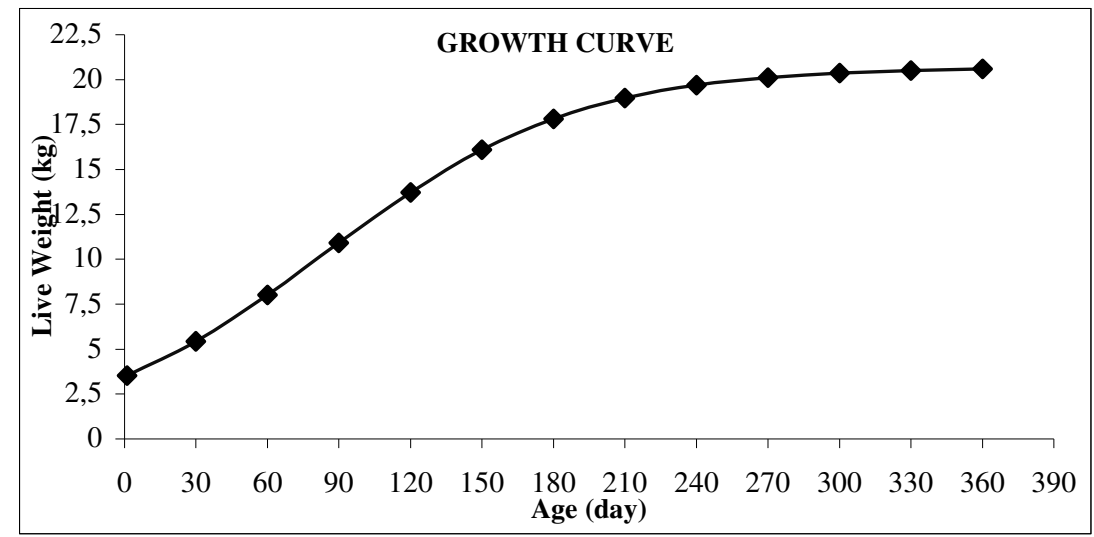

Figure 1. Growth curve by Logistic model in young Angora goat

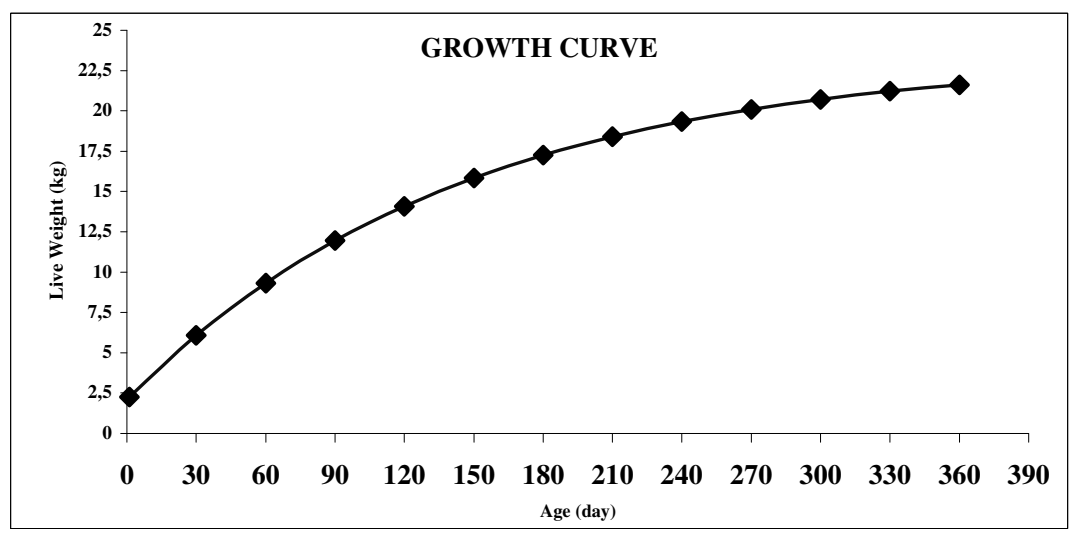

Figure 2. Growth curve by Gompertz model in young Angora goat

\section{Conclusions}

In this study, the growth curves between birth and $12^{\text {th }}$ months in the young Angora goats were determined by Logistic and Gompertz growth models. According to both models, while the shapes of growth curves showed linearity during the first 2 months after birth, this linearity changed to sigmoidal shape during the forward periods (approximately between $2-12^{\text {th }}$ months of ages). As a result, it might be suggested that it could be suitable to use both Logistic and Gompertz growth models (non-linear models) for drawing of growth curves from weight data in the young Angora goat.

\section{References}

Çıtak, B., T. Kesici, A. Eliçin ve Z. Kocabaş. 1998. Keçilerde Değişik Karakterler Bakımından Büyüme Eğrileri. II. National Animal Science Congress, Bursa-Turkey.

Efe, E. 1990. Büyüme Eğrileri. Cukurova University Natural Science Institute, Animal Science Department. PhD. Thesis, Adana-Turkey.

Finney, D.J. 1978. Growth Curves: Their Nature, Uses and Estimation. In: H. De Boer and J. Martin (Ed.) Patterns of Growth and Development in Cattle. Pp 658-672. Martinus- Nijhof, The Hogue. 
Friggens, N. C., M. Shanks, I. Kyriazakis, J.D. Oldham and T.H. McClelland. 1997. The growth and development of nine European sheep breeds. I. British reeds: Scottish Blackface , Welsh Mountain and Shetland. Animal Science 65(3): 409-426.

Karakuş, K., E. Eyduran, D. Kum, T. Özdemir and F. Cengiz. 2008. Determination of the best growth curve and measurement interval in Norduz male lambs. Journal of Animal and Veterinary Advances 7 (11): 1464-1466.

Kor, A., E. Başpınar, S. Karaca and S. Keskin. 2006. The determination of growth in Akkeci (White goat) female kids by various growth Models. Czech Journal of Animal Science 51(3): 110-116.

Kuzu, E. 2001. Kilis Keçisi Oğlaklarında Değişik Vücut Ölçüleri Bakımından Büyüme Eğrileri. Ankara University Natural Science Institute, Master Thesis, AnkaraTurkey.

Najari, S., A. Gaddoun, M. Ben Hamouda, M. Djemali and G. Khaldi. 2007a. Growth model adjustment of local goat population under pastoral conditions in Tunisian arid zone. Journal of Argonomy 6(1): 61-67.

Najari, S., A. Gaddour, M. Ouni, M. Abdennabi and M. Ben Hamouda. 2007b. Non genetic factors affecting local kids' growth curve under pastoral mode in Tunisian arid region. Journal of Biological Sciences 7(6): 1005-1016.

SPSS (1994). SPSS for Windows Release 6.0. SPSS Ins.

Şireli, H.D. 2002. Dorset Down X Akkaraman (GD1) Akkaraman ve Akkaraman x GD1 Genotipli Kuzularda Büyüme ve Bazı Büyüme Özelliklerinin Tekrarlanma Derecelerinin Tahmini. Ankara University Natural Science Institute, Ph.D. Thesis, Ankara-Turkey.
Thornley, J.H.M. and I.R. Johnson. 1990. Plant and Crop Modelling. A. Mathematical Approach to Plant and Crop Physiology. Clarenrand Press, Oxford, U.S.A.

Tekel, N. 1998. İvesi Kuzularının Süt Emme ve Mer'alanma Dönemlerinde Büyüme Eğrilerinin Cizilmesi Üzerine Bir Araştırma. Ankara University Natural Science Institute, Master Thesis, Ankara-Turkey.

Tekel, N., H.D. Şireli, M. Eliçin and A. Eliçin. 2005. Comparison of growth curve models on Awassi lambs. Indian Veterinary Journal 82:179-182.

Yakupoğlu, C. 1999. Etlik Piliçlerde Büyüme Eğrilerinin Kartşılaştırıması. Ege University Natural Science Institute, Master Thesis, Izmir-Turkey.

Zygoyiannıs, D., I. Kyriazakıs, C. Stamatarıs, N.C. Freggens and N. Katsaounis. 1997. The growth and development of nine European sheep breeds. 2. Grek breeds: Boutsko, Serres and Karagounika. Animal Science 5(3): 427-440.

\section{Correspondence Address:}

Gürsel DELLAL

Ankara University, Faculty of Agriculture

Department of Animal Science

06110 Diskapi, Ankara, Turkey

Tel: 0 (312) 5961371

E-mail: gdellal@agri.ankara.edu.tr 